\title{
STRATEGI KEPALA MADRASAH DALAM IMPLEMENTASI UJIAN MADRASAH BERSTANDAR NASIONAL BERBASIS KOMPUTER DIMIMAMBAUL ULUM DESA MAYONG KARANGGENENG LAMONGAN
}

\author{
Siti Aminah ${ }^{1}$, Laili Nusrotin ${ }^{2}$ Sutopo ${ }^{3}$ \\ Institut Pesantren Sunan Drajat Lamongan \\ Email: aminah@insud.ac.id1', lailinusrotin2@gmail.com², sutopodrajat@gmail.com³
}

Dikirim: 16 Nopember 2020 | Direvisi: 10 Januari 2021 | Dipublikasikan: 31 Januari 2021

\begin{abstract}
Abstraksi: Komputerisasi di dunia pendidikan menjadi sebuah keniscayaan masa depan sistem pendidikan di Indonesia. Hal tersebut tidak hanya pada manajemen ketenagaan saja melainkan pula pada aspek-aspek lain. Aspek yang kian meluas adalah pada sistem evaluasi atau penilaian pada proses belajar mengajar dan hasil belajar peserta didik. Bentuk komputerisasi pada sistem evaluasi atau penilaian tersebut berupa program ujian sekolah yakni dalam bentuk Ujian Madrasah Berstandar Nasional Berbasis Komputer (UMBN-BK). Implementasi program tersebut pada tataran teknis butuh persiapan yang luar biasa, karena masih belum meratanya pendidikan di Indonesia, baik dari segi fasilitas atau sarana dan prasarana yang ada serta mutu dari sumber daya manusianya dalam hal ini pendidik dan tenaga kependidikan baik pada sekolah negeri dan swasta. Sebagai sebuah program yang harus diimplementasikan, maka Ujian Madrasah Berstandar Nasional Berbasis Komputer (UMBN-BK) butuh sebuah strategi yang harus dilaksanakan oleh pimpinan lembaga pendidikan. Oleh karenanya penelitian ini dilakukan. Hasil dari penelitian ini, bahwa strategi kepala MI Mambaul Ulum Mayong Karangbinangun Lamongan melalui dua tahap, yaitu pemenuhan perangkat komputer yang dipakai oleh peserta didik, kemudian pembinaan secara teknis. Adapun kendala pada pemenuhan perangkat komputer yang dipakai oleh peserta didik, yakni terbatasnya dana anggaran, ruangan yang kurang memadahi, kurang terawatnya komputer lama, sedangkan pada kendala pembinaan secara teknis terbatasnya sumber daya manusia.
\end{abstract}

Kata kunci: digitalisasi; pendidikan, evaluasi, belajar.

\section{Pendahuluan}

Pendidikan di era modern ini merupakan suatu yang menjadi kebutuhan mutlak yang harus terpenuhi demi terciptanya kemandirian dan kemajuan suatu bangsa. Kemandirian yang menurut Muhaimin pada aspek pribadi, yakni aspek mental dan sosial. ${ }^{1}$ Sebagaimana tujuan pendidikan nasional yang telah termaktub dalam Pembukaan Undang-Undang Dasar Tahun 1945 alinea keempat. ${ }^{2}$ Hal tersebut juga dijelaskan dalam Undang-Undang Nomor 20 Tahun 2003 Tentang

\footnotetext{
${ }^{1}$ Hasan Basri, Filsafat Pendidikan Islam (Bandung: Pustaka Setia, 2014), 54.

${ }^{2}$ Cita-cita bangsa Indonesia merdeka antara lain: melindungi segenap bangsa Indonesia dan seluruh tumpah darah Indonesia; (2) memajukan kesejahteraan umum; (3) mencerdaskan kehidupan bangsa; dan (4) ikut melaksanakan ketertiban dunia yang berdasarkan kemerdekaan, perdamaian abadi dan keadilan sosial. Baca lebih lengkapnya, Yahanes Suhardin, "Peranan Negara dan Hukum dalam Memberantas Kemiskinan dengan mewujudkan Kesejahteraan Umum", Jurnal Hukum dan Pembangunan, Volume 42, Nomor 3 (Juli-September 2012): 303.
} 
Sistem Pendidikan Nasional, yang menjelaskan bagaimana untuk mencapai tujuan kebijakan pada ranah pendidikan yakni dengan disusunnya sebuah kurikulum pendidikan yang tepat. ${ }^{3}$

Pendidikan sebagai sebuah sistem yang begitu penting dalam perwujudan kualitas sumber daya manusia sebuah bangsa, selain diperlukan pengelolaan yang baik, perlu juga adanya penyesuaian dengan perkembangan zaman agar luaran lembaga pendidikan juga menghasilkan manusia-manusia yang berkualitas dan sesuai dengan kebutuhan zaman pula. ${ }^{4}$ Oleh karena itu, pemerintah berupaya meningkatkan kualitas pendidikan baik dari sisi perencanaan, implementasi dan evaluasi. Sehingga dikeluarkan berbagai kebijakan terkait implementasi sistem pendidikan di Indonesia.

Salah satu upaya yang dilakukan pemerintah terkait penataan sistem pendidikan di Indonesia adalah dengan melakukan kebijakan terkait Ujian Sekolah Berstandar Nasional (USBN) yang mana tidak lagi dilakukan dengan ujian tulis melainkan dengan ujian berbasis komputer ${ }^{5}$ atau yang disebut dengan Ujian Sekolah Berstandar Nasional Berbasis Komputer (USBNBK). ${ }^{6}$ Kebijakan ini perlu dikawal secara intensif dikarenakan banyak faktor yang mempengaruhi suksesnya pelaksanaan suatu kebijakan, dalam hal ini kebijakan USBNBK. Perlunya kawalan ini sebagai dampak kurang meratanya pendidikan di Indonesia, baik dari segi Sumber Daya Manusia (SDM), sarana dan prasarana dan yang lain, yang belum bisa tersebar secara merata di seluruh wilayah di Indonesia.

Pelaksanaan kebijakan dari pemerintah pusat dilihat dari sisi manajemen dilakukan secara berjenjang mulai dari kementerian di Jakarta hingga pada lembaga pelaksana yang ada di sekolah pada masing-masing daerah. Maka dalam hal ini, banyak melibatkan banyak orang atau pejabat terkait dalam proses persiapan hingga pada evaluasi kebijakan. Jika mengkerucut pada level lembaga pendidikan, maka peran pimpinan lembaga begitu besar dalam upaya pelaksanaan Ujian Sekolah Berstandar Nasional Berbasis Komputer (USBNBK).

Tahap-tahap yang perlu dilakukan baik dari level pusat hingga pada satuan pendidikan adalah adanya perencanaan yang matang sebelum proses implementasi dan evaluasi dari kebijakan USBNBK yang telah ditetapkan. Dari sini bisa kita tandaskan bahwa peran pimpinan satuan pendidikan dalam hal ini adalah kepala madrasah atau sekolah menjadi sangat penting, baik sebagai perencana, pengorganisasi, pelaksana, pengelola tenaga kependidikan dan pengawas atau supervisor pelaksanaan pendidikan di lembaga yang dipimpinnya.

\footnotetext{
${ }^{3}$ Supardi U. S., "Arah Pendidikan di Indonesia dalam Tataran Kebijakan dan Implementasi”, Jurnal Formatif, Volume 2, Nomor 2, (Agustus, 2012): 116-118. http://dx.doi.org/10.30998/formatif.v2i2.92.

${ }^{4}$ Adri Efferi, "Mengelola Lembaga Pendidikan di Era Global (Pergeseran Paradigma Bisnis Menjadi Bisnis)" Quality: Jurnal Pendidikan Islam, Volume 3 Nomor 1, (Juni, 2015): 6.

${ }^{5}$ Baca Peraturan Menteri Pendidikan dan Kebudayaan Nomor 43 tahun 2019 Tentang Penyelenggaraan Ujian Yang Diselenggarakan Satuan Pendidikan dan Ujian Nasional Pasal 14 Ayat (1) dan (2).

${ }^{6}$ Kebijakan USBN sejak tahun 2018 telah dilakukan dengan menggunakan perangkat komputer dan kertas baca lebih lengkap pada Buletin BSNP: Media dan Dialog Standar Pendidikan, Volume 8, Nomor 1, (Maret, 2018): 3-5.
} 
Implementasi kebijakan Kementerian Pendidikan dan Kebudayaan, yakni Ujian Madrasah Berstandar Nasional Berbasis Komputer (UMBN-BK) di lembaga pendidikan pastinya tidak semua berjalan mulus, dikarenakan kondisi lapangan begitu berbeda dengan apa yang diangankan. Bermacam-macam kendala pasti ada khususnya terkait Sumber Daya Manusia (SDM) serta sarana dan prasarana. Kondisi tersebut terjadi pula pada lembaga MI Manbaul Ulum Desa Mayong Kecamatan Karangbinangun Kabupaten Lamongan. berdasarkan penelitian awal yang dilakukan oleh peneliti bahwa implementasi USBN-BK pada sekolah ini dilaksanakan dengan beberapa kendala, diantaranya: keadaan SDM yang masih belum kompeten dalam bidang TIK; sarana dan prasarana yang masih terbatas. ${ }^{7}$ Namun hal tersebut tak menjadi halangan bagi terselenggaranya USBN-BK di MI Manbaul Ulum Mayong Karangbinangun Lamongan, yang mana lembaga ini merupakan bagian dari salah satu lembaga yang siap melaksanakan USBN-BK dibandingkan dengan sekolah lain disekitarnya.

Dari pemaparan di atas, maka hal yang menarik yang menjadi alasan kuat peneliti melakukan penelitian di lembaga ini adalah bagaimana strategi kepala madrasah sehingga lembaga ini siap dan sukses dalam pelaksanaan Ujian Sekolah Berstandar Nasional Berbasis Komputer pada tahun 2020 dibanding lembaga disekitarnya.

\section{Metode Penelitian}

Pendekatan dan Jenis Penelitian

Penelitian ini menggunakan rancangan penelitian dengan menggunakan penelitian deskriptif kualitatif. penelitian deskriptif kualitatif adalah penelitian yang bermaksud untuk memahami fenomena tentang apa yang dialami oleh subjek penelitian misalnya tentang perilaku persepsi, tindakan, dll. Secara holistik dan dengan cara deskripsi dalam bentuk kata-kata dalam bahasa, pada suatu konteks khusus yang alamiah dan dengan memanfaatkan berbagai metode ilmiah. ${ }^{8}$

Deskriptif kualitatif ini digunakan penulis untuk menganalisis strategi kepala madrasah dalam implementasi ujian sekolah berstandar nasional berbasis komputer yang ada di Lembaga MI Mambaul Ulum Desa Mayong Kecamatan Karangbinangun Kabupaten Lamongan. Fokus penelitian yang ada pada skripsi yaitu difokuskan pada suatu keadaan atau fenomena yang ada tentang strategi kepala madrasah yang pengelolaanya ditekankan untuk mengimplementasikan ujian sekolah berstandar nasional berbasis komputer. Dari sini penulis juga bermaksud untuk mengetahui strategi apa yang dipakai oleh kepala madrasah dalam implementasi ujian nasional berstandar nasional berbasis komputer

\footnotetext{
${ }^{7}$ M. Munif, Wawancara, Lamongan 21 Maret 2020, Pada 09.00 - 10.00 WIB.

${ }^{8}$ Lexy J. Moleong, Metode Penelitian Kualitatif (Bandung: Remaja Rosdakarya, 2016), 6.
} 


\section{Deskripsi Latar Penelitian}

Dalam Penelitian ini lokasi penelitian dilakukan di MI Mambaul Ulum Desa Mayong Kecamatan Karangbinangun Kabupaten Lamongan. peneliti melakukan penelitian di lembaga tersebut dikarenakan ingin menngetahui strategi kepala madrasah dalam implementasi ujian sekolah berstandar nasional berbasis komputer. Selain itu MI Mambaul Ulum adalah salah satu sekolah yang menggunakan komputer sebagai ujian sekolah berstandar nasional pertama kali di banding sekolah-sekolah lainya, sarana prasana yang cukup memadahi dan strategi seorang kepala madrasah juga ingin peneliti teliti lebih lanjut.

\section{Instrumen Penelitian}

Dalam penelitian kualitatif instrumen utamanya adalah peneliti sendiri, namun selanjutnya setelah fokus penelitian menjadi jelas, maka kemungkinan akan dikembangkankan instrumen penelitian sederhana, yang diharapkan dapat melengkapi data dan membandingkan dengan data yang telah ditemukan melalui observasi dan wawacara, peneliti akan terjun kelapangan sendiri baik pada pengumpulan data, analisis data dan membuat kesimpulan. ${ }^{9}$

Nasution, menyatakan bahwa observasi adalah dasar semua ilmu pengetahuan, para ilmuan hanya dapat bekerja berdasarkan data, yaitu fakta mengenai dunia kenyataan yang diperoleh melalui observasi. Data itu dikumpulkan dan sering dengan bantuan berbagai alat yang sanggat canggih, sehingga benda-benda yang sanggat kecil (proton dan eloktron)maupun yang sangat jauh (benda ruang angkasa) dapat diobservasi dengan jelas. ${ }^{10}$ Dalam penelitian ini peneliti melakukan penggamatan terhadap objek penelitian yang berkaitan dengan strategi kepala madrasah dalam implementasi Ujian Sekolah Berstandar Nasional Berbasis Komputer.

Esterberg mendefinisikan interview/ wawancara Wawancara adalah merupakan pertemuan dua orang untuk bertukar informasi dan ide melalui Tanya jawab, sehingga dapat dikonstruksikan makna dalam suatu topik tertentu. ${ }^{11}$

Jenis wawancara yang digunakan peneliti adalah wawancara terstruktur, wawancara terstruktur digunakan sebagai teknik pengumpulan data bila peniliti atau pengumpulan data telah mengetahui dengan pasti tentang informasi apa yang akan diperoleh, oleh karena itu dalam melakukan wawancara, pengumpul data telah menyiapkan instrumen penelitian berupa pertanyaanpertanyaan tertulis yang alternatif setiap responden diberi pertanyaan yang sama, dan pengumpul data mencatatnya, dengan wawancara terstruktur ini pula, pengumpulan data dapat menggunakan

\footnotetext{
${ }^{9}$ Sugiyono, Metode Penelitian Pendidikan pendekatan kuantitatif, kualitatif, dan R \& D (Bandung: Alfabeta, 2013), 307.

10 Ibid., 310.

11 Ibid., 317.
} 
beberapa pewancara sebagai pengumpul data, supaya setiap pewancara mempunyai keterampilan yang sama, maka diperlukan training kepada calon pewawancara.

\section{Data dan Sumber Data}

Data primer adalah data yang dikumpulkan oleh peneliti sendiri dari sumber pertamanya. ${ }^{12}$ Adapun yang menjadi sumber data primer dalam penelitian ini adalah kepala madrasah, waka kurikulum, waka kesiswaan, waka sarpars dan guru MI Mambaul Ulum. Sedangkan data sekunder yaitu data yang dikumpulkan oleh peneliti sebagai penunjang dari sumber pertama. Dapat juga dikatakan data yang tersusun dalam bentuk dokumen-dokumen. ${ }^{13}$ Dalam penelitian ini wawancara, obsevasi dan realisasi Dokumen merupakan sumber data sekunder.

\section{Teknik Analisis Data}

Analisis data dalam penelitian kualitatif, dilakukan pada saat pengumpulan data berlangsung, dan setelah selesai pengumpulan data dalam periode tertentu, pada saat wawancara, peneliti sudah melakukan analisis terhadap jawaban yang diwawancarai, jika jawaban yang diwawancarai setelah dianalisis terasa belum memuaskan, maka peneliti akan melanjutkan pertanyaan lagi, sampai tahap tertentu, diperoleh data yang dianggap kredibel.

Miles and Huberman mengemukakan bahwa aktivitas dalam analisis data kualititatif dilakukan secara interaktif dan berlangsung secara terus menerus sampai tuntas, sehingga datanya sudah jenuh, aktivitas dalam analisis data, yaitu, data reduction, data display, dan conclusion drawing/verification. ${ }^{14}$

\section{Pemeriksaan Keabsahan Data}

Untuk memperoleh tingkat keabsahan data, peneliti mengunakan teknik antara lain:

\section{Ketekunan Pengamatan}

Ketekunan pengamatan yakni serangkaian kegiatan yang dibuat secara terstruktur dan dilakukan secara serius dan berkesinambungan terhadap segala realistis yang ada di lokasi penelitian dan untuk menemukan ciri-ciri dan unsur-unsur dalam situasi yang sangat relevan dengan persoalan atau peristiwa yang sedang dicari kemudian difokuskan secara terperinci dengan melakukan pengamatan mendalam. ${ }^{15}$ Maka dalam hal ini peneliti diharapkan mampu

\footnotetext{
${ }^{12}$ Sumadi Suryabarata, Metode Penelitian (Jakarta: Rajawali, 1987), 93.

13 Ibid., 94.

${ }^{14}$ Sugiyono, Metode Penelitian Pendidikan pendekatan kuantitatif, kualitatif, dan R\&D (Bandung: Alfabeta, 2013$), 337$.

${ }^{15}$ Lexy J. Moleong, Metode Penelitian Kualitatif (Bandung: Remaja Rosdakarya, 2016), 329.
} 
menguraikan secara rinci berkesinambungan terhadap proses bagaimana penemuan secara rinci tersebut dapat dilakukan.

2. Triangulasi

William Wiersma, mengatakan triangulasi dalam pengujian kredibilitas ini diartikan sebagai pengecekan data dari berbagai sumber dengan berbagai cara, dan berbagai waktu, dengan demikian terdapat 3 macam triangulasi yaitu : triangulasi sumber, triangulasi teknik dan triangulasi waktu.

\section{Paparan Data Penelitian dan Pembahasan}

Dalam Paparan Data Temuan Penelitian pada Madrasah Ibtidaiyah Mambaul Ulum di Desa Mayong Kecamatan Karangbinangun Kabupaten Lamongan dengan berdasarkan rumusan masalah maka didapat sebagai berikut:

1. Strategi Kepala Madrasah dalam Implementasi Ujian Sekolah Berstandar Nasional Berbasis Komputer di MI Mambaul Ulum di Desa Mayong Kecamatan Karangbinangun Kabupaten Lamongan.

Arus globalisasi telah memicu kecenderungan pergeseran dalam dunia pendidikan dan pendidikan tatap muka yang konversioanal ke arah pendidikan yang lebih terbuka, pendidikan mendatang akan lebih luwes (flexsibel), terbuka dan dapat diakses oleh siapapun yang memerlukan tampa pandangan faktor jenis, usia maupun pengalaman pendidikan sebelumnya, pendidikan mendatang akan lebih ditentukan oleh jaringan komunikasi yang memungkinkan berinteraksi dan berkolaborasi, bukannya berorientasi pada gedung sekolah. ${ }^{16}$

Peningkatan mutu pendidikan semakin diarahkan pada perluasan inovasi pembelajaran baik dengan formal maupun non formal dalam rangka untuk mewujudkan nilai tambah berupa efisiensi, menyenangkan dan mencerdaskan peserta didik sesuai dengan tingkat usia kematangan dan perkembangan peserta didik.

Peyelenggaraan ujian sekolah berstandar nasional berbasis komputer merupakan inovasi yang bertujuan dalam pengembangan mutu pendidikan yang mengacu pada Kebijakan Peraturan Menteri Pendidikan Dan Kebudayaan Republik Indonesia Nomor 4 Tahun 2018 tentang Penilaian Hasil Belajar Oleh Satuan Pendidikan Dan Penilaian Hasil Belajar Oleh Pemerintah serta Peraturan Badan Standar Nasional Pendidikan Nomor:

${ }^{16}$ Oom Mukarromah, "Peran Teknologi Pendidikan Islam pada Era Global", AN-NIDHOM, Volume 1, Nomor 2, (Juli-Desember 2016): 104. 
0048/BSNP/XI/2018 tentang Prosedor Operasional Standar Peyelenggaraan Ujian Sekolah Berstandar Nasional Tahun Pelajaran 2018/2019.

MI Mambaul Ulum melaksanakan ujian sekolah berstandar nasional berbasis komputer, dan tidak lepas dari 4 aspek penting yaitu, bentuk soal ujian berupa pilihan ganda dan uraian, kesiapan infrastruktur, kesiapan aplikasi, kesiapan sumber daya manusia. Dalam implementasi ujian sekolah berstandar nasional berbasis komputer sesuai dengan wawancara dan observasi yang peneliti peroleh mengenai pengelolaan strategi yang tidak lepas dari analisis POAC yaitu planning (perencanaan) organizing (pengorganisasian) actuating (pelaksanaan) dan controling (pengawasan).

a. Perencanaan

Dalam implementasi ujian sekolah berstandar nasional berbasis komputer perlu adanya perencanaan yang matang dalam mengolah strategi. Dari hasil wawancara dapat disimpulkan bahwa ada dua strategi yang merupakan trik yang dilakukan kepala madrasah dalam implementasi ujian sekolah berstandar nasional berbasis computer yaitu strategi pemenuhan perangkat komputer dan strategi pembinaan secara teknis. Dijelaskan pula spesifikasi komputer hardware server proktor disarankan menggunakan spesifikasi minimal prosesor core I5, Memory RAM 8GB, Hardisk 500GB, koneksi jaringan internet/ LAN (Local Area Network). Sedangkan pada Strategi pembinaan secara teknis dan melakukan sharing dengan proktor oleh kabupaten untuk memberikan pelatihan sebagai berikut: Install aplikasi ujian sekolah berstandar nasional berbasis komputer hingga backup data.

b. Pengorganisasian

Pengorganisasian strategi kepala madrasah dalam implementasi ujian sekolah berstandar nasional berbasis komputer yang meliputi:

1) Pemenuhan perangkat komputer

Setiap strategi harus diolah dengan baik dan terarah pemenuhan kriteria persyaratan infrastruktur ujian sekolah berstandar nasional berbasis komputer merupakan strategi pemenuhan komputer oleh madrasah dari hasil wawancara dapat disimpulkan, dalam Pemenuhan komputer yang paling diperhatikan oleh kepala madrasah adalah infrastruktur yang sesuai dengan kriteria yang disahkan oleh pusat. Sedangkan pengadaan komputer sudah jadi pemenuhan yang wajib dimiliki madrasah. 
2) Pembinaan secara teknis

Dalam tahap pengorganisasian pembinaan secara teknis oleh Kepala Madrasah yaitu melakukan pembagian kerja yang jelas terhadap Guru dan karyawan madrasah yang terlibat dalam kegiatan ujian sekolah berstandar nasional berbasis komputer. Untuk itu perlu peran kepala madrasah sebagai pemimpin untuk mengarahkan bawahanya dalam melakukan tugas tersebut. Adapun prinsip yang harus diperhatikan adalah kejelasan tugas setiap tim sukses, setiap bawahan menerima dan mengetahui tiap tugas yang diberikan, Dari wawancara tersebut dapat disimpulkan bahwasanya pengorganisasian merupakan tahapan saling bekerjasamanya kepala madrasah dalam membina dan mengatur implementai ujian sekolah berstandar nasional berbasis komputer, mengatur setiap tupoksi dan tugas seperti proktor dan teknisi.

c. Pelaksanaan

Pelaksanaan strategi kepala madrasah dalam implementasi ujian sekolah berstandar nasional berbasis komputer yang meliputi:

1) Strategi pemenuhan perangkat komputer yang dipakai oleh siswa

Dalam pemenuhan komputer untuk pelaksanaan strategi pemenuhan perangkat komputer yang dipakai oleh peserta didik. Untuk itu dalam pelaksanaan strategi pemenuhan perangkat komputer harus memperhatikan kriteria yang di ajukan oleh pusat. Kerjasama juga dibutuhkan dalam implementasi ujian sekolah berstandar nasional berbasis komputer

2) Strategi pembinaan secara teknis

Dalam strategi pembinaan secara teknis bahwasanya implementasi ujian sekolah berstandar nasional berbasis komputer telah terlaksana dengan baik adanya monitoring dan evaluasi oleh Dinas Pendidikan Kabupaten.

d. Pengaawasan

Dalam pengawasan peran aktif kepala sekolah tidaklah imbang jika tidak diimbangi dengan pengawasan secara langsung maupun tidak langsung. Meskipun kepala sekolah sudah menentukan dan membentuk kepanitiaan tetapi tetap saja yang paling bertanggung jawab, Dari wawancara tersebut dapat disimpulkan bahwa pengawasan ujian sekolah berstandar nasional berbasis komputer yaitu tindakan kepala madrasah dalam mengawasi setiap tupoksi yang ada seperti proktor, teknisi, dan dewan guru lainya setiap elemen tupoksi memiliki tugas dan peran sendiri dalam implementasi ujian sekolah berstandar nasional berbasis komputer. 
2. Kendala Penerapan Strategi Kepala Madrasah dalam Implementasi Ujian Sekolah Berstandar Nasional Berbasis Komputer di MI Mambaul Ulum di Desa Mayong Kecamatan Karangbinangun Kabupaten Lamongan.

Implementasi ujian sekolah berstandar nasioanal berbasis komputer merupakan gerbang peserta didik dalam menyelesaikan tugas akhir sebagai peserta didik jenjang madrasah maka perlu diadakanya beberapa strategi untuk melaksanakan kegiatan ujian dengan maksimal adapun dalam pemenuhan strategi tersebut menemukan beberapa kendala yang mungkin terjadi ditengah berlangsungnya kegiatan ujian sekolah berstandar nasioanal berbasis komputer berlangsung.

Ada beberapa kendala yang bisa ditemukan dalam penelitian ini. Kendala tersebut terdiri dari kendala Sumber Daya Manusia (SDM), baik dari pihak pendidik dan Peserta didik serta kendala sarana dan prasarana yang meliputi; Terbatasnya dana anggaran belanja untuk penyediaan komputer; ruangan yang kurang memadai; dan perawatan komputer yang kurang maksimal.

Kendala terkait minimnya penguasaan IT oleh pendidik dan tenaga pendidikan serta peserta didik menjadi hal yang perlu disikapi secara cepat dan tepat. Solusi yang diambil oleh kepala sekolah adalah dengan mendelegasikan operator ujian, dalam hal ini guru yang telah ditunjuk untuk mengikuti pelatihan yang diselenggarakan oleh KKM dan Dinas Pendidikan serta Kementerian Agama Kabupaten Lamongan. serta adanya pendampingan kepada peserta didik secara internal dengan melakukan simulasi Ujian Madrasah Berstandar Nasional Berbasis Komputer.

Kendala terkait terbatasnya unit komputer sebagai sarana pelaksanaan Ujian Madrasah Berstandar Nasional Berbasis Komputer, maka yang dilakukan oleh pihak lembaga dalam hal ini lembaga harus menyampaikan kondisi kepada wali murid tentang sarana prasana yang kurang memadahi sehingga perlu diadakanya solusi yang dapat dilakukan sebelum masalah menjadi besar.

Komputer merupakan alat yang digunakan sebagai monitor ujian sekolah bertandar nasional berbasis komputer yang berisi aplikasi ujian sekolah bertandar nasional berbasis komputer sehingga jika ketersediaan komputer kurang memadahi maka ujian sekolah berstandar nasional berbasis komputer bisa terhambat atau batal dilaksanakan. Solusinya yaitu dengan meminjam komputer milik guru maupun milik orang tua wali murid bila diperlukan. 
Kendala yang sering terjadi setelah jumlah komputer kurang memadahi yaitu ruangan yang kurang memadahi, jika ruangan kurang memadahi maka kendala ini cukup bermasalah sebab ruangan merupakan tempat dimana komputer di simpan. Tempat pengaturan jaringan LAN (local area network) dan jika menggunakan lebih dari satu ruangan membutuhkan wifi yang lebih besar lagi. Selain itu pengawas lebih dari 2 pengawas juga dibutuhkan. Solusi dari masalah ini adalah mengatur peserta didik menjadi 2 gelombang.

Terkain kendala perawatan komputer yang tidak dipakai dalam kurun waktu lebih dari 1 bulan jika tidak dirawat maka akan banyak menemukan masalah. komputer yang jarang digunakan juga akan mengalami banyak masalah seperti terancam ulah tikus, kelembapan ruangan, debu, dan serangga kecil lainya sehingga perlu adanya solusi dalam penjadwalan piket.

\section{Kesimpulan}

Dari hasil penelitian yang dilakukan oleh peneliti di MI Mambaul Ulum di Desa Mayong Kecamatan Karangbinangun Kabupaten Lamongan dan setelah penulis memaparkan pembahasan tentang Strategi Kepala Madrasah Dalam Implementasi Ujian Sekolah Berstandar Nasional Berbasis Komputer di Desa Mayong Kecamatan Karangbinangun Kabupaten Lamongan, maka penulis menarik beberapa kesimpulan sebagai berikut: Strategi kepala madrasah dalam implementasi ujian sekolah berstandar nasional berbasis komputer di MI Mambaul Ulum di Desa Mayong Kecamatan Karangbinangun Kabupaten Lamongan mengunakan dua tahapan sebagai konsep strategi kepala madrasah dalam implementasi ujian sekolah berstandar nasional berbasis komputer yaitu strategi pemenuhan komputer yang dipakai oleh siswa, kemudian strategi pembinaan secara teknis. Kendala penerapan strategi kepala madrasah dalam implementasi ujian sekolah berstandar nasional berbasis komputer di MI Mambaul Ulum di Desa Mayong Kecamatan Karangbinangun Kabupaten Lamongan yaitu pada pemenuhan perangkat komputer yang dipakai oleh siswa ada berbagai macam kendala diantaranya yaitu terbatasnya dana anggaran belanja untuk penyediaan komputer, ruangan yang kurang memadahi, kurang terawatnya komputer lama, sedangkan kendala pada strategi pembinaan secara teknis terbatasnya sumber daya manusia.

Berdasarkan hasil penelitian, pembahasan dan kesimpulan di atas, penulis memberikan saran yang bertujuan untuk kebaikan dan kemajuan MI Mambaul Ulum di Desa Mayong Kecamatan Karangbinangun Kabupaten Lamongan, sebagai berikut: Diharapkapkan kepada MI Mambaul Ulum untuk lebih menekankan pengadaan komputer dan memenuhi perangkat-perangkat yang dibutuhkan untuk ujian sekolah berstandar nasional berbasis komputer. Selain itu lebih menekankan pelajaran teknologi informasi dan komunikasi sebagai bentuk bimbel (bimbingan belajar) atau les 
kepada peserta didik. Bagi guru dan segenap karyawan MI Mambaul Ulum hendaknya ikut mengajarkan kepada peserta didik bagaimana menggunakan komputer dan merawat komputer. Diharapkan kepada para sarjana Manajemen Pendidikan Islam lebih aktif memberikan sumbangan pemikiran yang bisa memberikan solusi terhadap kendala-kendala yang ada dan dapat memberikan kajian-kajian yang lebih mendalam dan lebih luas mengenai strategi kepala madrasah dalam implementasi ujian sekolah berstandar nasional berbasis komputer.

\section{Daftar Kepustakaan}

Basri, Hasan. Filsafat Pendidikan Islam. Bandung: Pustaka Setia, 2014.

Efferi, Adri "Mengelola Lembaga Pendidikan di Era Global (Pergeseran Paradigma Bisnis Menjadi Bisnis)" Quality: Jurnal Pendidikan Islam, Volume 3 Nomor 1, (Juni, 2015): 6.

Kementerian Pendidikan dan Kebudayaan, Buletin BSNP: Media dan Dialog Standar Pendidikan, Volume 8, Nomor 1, (Maret, 2018): 3-5.

Moleong, Lexy J. Metode Penelitian Kualitatif . Bandung: Remaja Rosdakarya, 2016.

Mukarromah, Oom. "Peran Teknologi Pendidikan Islam pada Era Global", AN-NIDHOM, Volume 1, Nomor 2, (Juli-Desember 2016): 104.

Peraturan Menteri Pendidikan dan Kebudayaan Nomor 43 tahun 2019 Tentang Penyelenggaraan Ujian Yang Diselenggarakan Satuan Pendidikan dan Ujian Nasional Pasal 14 Ayat (1) dan (2).

Suhardin, Yahanes. "Peranan Negara dan Hukum dalam Memberantas Kemiskinan dengan mewujudkan Kesejahteraan Umum", Jurnal Hukum dan Pembangunan, Volume 42, Nomor 3 (Juli-September 2012): 303.

U. S., Supardi. "Arah Pendidikan di Indonesia dalam Tataran Kebijakan dan Implementasi”, Jurnal Formatif, Volume 2, Nomor 2, (Agustus, 2012): 116-118. http://dx.doi.org/10.30998/formatif.v2i2.92.

Sugiyono, Metode Penelitian Pendidikan pendekatan kuantitatif, kualitatif, dan $R \& D$. Bandung: Alfabeta, 2013.

Suryabarata, Sumadi. Metode Penelitian. Jakarta: Rajawali, 1987.

M. Munif, Wawancara, Lamongan 21 Maret 2020, Pada 09.00 - 10.00 WIB. 